Revue Française de Civilisation Britannique

\title{
The December 2019 UK General Election:
}

\section{Reflections}

Les Élections législatives de décembre 2019 au Royaume-Uni: quelques réflexions

\section{Philip Rycroft}

\section{(2) OpenEdition}

\section{Journals}

Electronic version

URL: http://journals.openedition.org/rfcb/5846

DOI: $10.4000 /$ rfcb. 5846

ISSN: 2429-4373

\section{Publisher}

CRECIB - Centre de recherche et d'études en civilisation britannique

Electronic reference

Philip Rycroft, « The December 2019 UK General Election: Reflections », Revue Française de Civilisation Britannique [Online], XXV-3 | 2020, Online since 10 September 2020, connection on 10 December 2020. URL : http://journals.openedition.org/rfcb/5846 ; DOI : https://doi.org/10.4000/rfcb.5846

This text was automatically generated on 10 December 2020 .

\section{(9) $\odot \Theta \Theta$}

Revue française de civilisation britannique est mis à disposition selon les termes de la licence Creative Commons Attribution - Pas d'Utilisation Commerciale - Pas de Modification 4.0 International. 


\section{The December 2019 UK General Election: Reflections}

Les Élections législatives de décembre 2019 au Royaume-Uni: quelques réflexions

\section{Philip Rycroft}

\section{Introduction}

1 The 2019 general election was the election that the Conservative party should not have won. A party that had for over three years been bitterly divided on Brexit, by far and away the dominant issue of British politics, was seeking a fourth term in office. Its achievements in government in terms of policy outcomes since the 2016 Brexit referendum were uninspiring at best. It had overseen a decade of austerity that had stretched the social fabric of the country thin.

2 A divided party, a party worn out by the travails of nine years of difficult government, a party without a substantial record of policy success; by all the normal rules of politics, this election should have been there for the taking by the opposition.

Yet the Conservative party not only won, but won well, achieving a majority of 80 , the best performance by the party since Mrs Thatcher in the election of 1987. This was at the outer edge of what even the most optimistic of party supporters thought was achievable, way out-doing David Cameron's hard fought majority victory in 2015 and a major turn-around on Mrs May's dismal effort in 2017.

4 Why did the Conservative party win so handsomely? Is this decisive outcome a sign of the end of Brexit divisions in the UK? Have the Conservatives succeeded in breaking the mold of British politics? 


\section{The Conservatives' handsome victory}

5 Through a hard-fought campaign, two main factors intertwined to produce this emphatic outcome: Brexit and the failure of the leadership of the main opposition party, Labour.

The election outcome can be seen as the culmination of the 2016 EU referendum campaign. British politics since June 2016 had been riven by the question of whether, and if so, how the UK should leave the EU. Through the three tortured years of the May premiership, everything remained in doubt.

7 The endeavour started bravely enough, with the ambiguous, if ultimately vacuous, slogan: 'Brexit means Brexit'. But, confronted with the hard reality that there was a binary choice to be made between a close relationship along the lines of the European Economic Area or a looser Canada-style free trade agreement, the May government became paralyzed between the opposing factions within her own party.

Having ruled out the continuation of free movement, the logic of her position drove her to espouse a relationship based on a free trade agreement. Belatedly, she came to recognise the risk that this would pose both to existing patterns of trade between the UK and the EU and to the coherence of the UK Union itself, specifically in relation to Northern Ireland. Her attempt to find a middle way for the future relationship, retaining close regulatory alignment in an unprecedented customs arrangement, pleased few. But she never got to test whether it was a sustainable basis for a future relationship. In three times of asking, Parliament decisively rejected the Withdrawal Agreement she had negotiated.

With the opposition parties unwilling to support the May deal but unable to win a majority in Parliament for any alternative, Brexit policy was at an impasse. The divisions generated by the referendum campaign, far from healing, were as deep as ever. Many still believed that somehow Brexit could be averted, many others despaired at the failure to deliver on the outcome of the referendum.

Into this toxic mix the new leader of the Conservative party from July 2019, Boris Johnson, injected a proposition of simple clarity. The UK would leave the EU, come what may, and would negotiate what could only be described as a hard Brexit, a free trade agreement with minimal regulatory alignment. To give credence to that policy position, he unceremoniously ejected from the Conservative party those who would not fall into line behind it.

11 This is the proposition that he took into the election campaign, under the taut and effective slogan of 'Get Brexit Done'. Despite having missed his first self-imposed deadline for leaving the EU of 31 October and despite the perceived chicanery of his attempt to prorogue Parliament, this was the position that cut through with the electorate.

Brexit was no doubt the dominant issue of the campaign. The country had a clear choice before it, to end the prevarication of three years of political turmoil or to commit to a further re-opening of the terms of exit and an uncertain future beyond that. Despite Opposition attempts to bring more quotidian issues to the fore, notably the NHS, for those who voted for the Conservative party, Brexit was the top issue. ${ }^{1}$

The Conservative party succeeded broadly in uniting those in favour of Brexit behind it. According to YouGov post-election analysis, the Conservatives increased their share 
of Leave voters from the 2017 election from $65 \%$ to $74 \%{ }^{2}$ The Brexit party in the end did not pose a serious challenge. Choosing not to stand in seats where the Conservative candidate was firmly in the Brexit camp, its share of the vote fell to a mere $2 \%$. Meanwhile, those who opposed Brexit, at least in the form proposed by Johnson, split their vote between the opposition parties. Labour actually lost share of the Remainer vote, down from $55 \%$ in 2017 to just $49 \%$.

The election thereby settled the question that had remained open since June 2016. The UK would leave the EU, and did so formally on 31 January 2020, and would thereafter negotiate a thin free trade agreement which would allow for substantial divergence from the EU market.

The Conservatives seized the advantage of real clarity on the big issue of the day. They were able to capitalise on the anger and disappointment in the country that the Brexit promise had not already been delivered. Their task in doing this was made immeasurably easier by the ambiguity of the Labour party's position on Brexit.

\section{Labour's dramatic defeat}

Riven by its own divisions on Brexit, and with Jeremy Corbyn as a leader who was at best ambivalent in his own attitude to the European Union, Labour had struggled to create a policy that had cut through with the voters. There was no easy middle ground for Labour that would satisfy both their young and professional supporters in urban centres and university towns and their more traditional voters in Leave-supporting seats in the midlands and north of England.

The party went through a series of every more tortured compromises. By committing to a renegotiation of the Withdrawal Agreement and a subsequent referendum on the deal alongside an option to remain, but unable to say what it would as a party recommend in that referendum, the party's position in the election campaign left many people confused and, at the margins, laid it open to ridicule. The policy might have been sufficient to draw back some Remain voters who were put off by the unequivocal commitment of the Liberal Democrats to outright revocation of the Article 50 letter, but it had no reach into Labour's own Brexit-leaning heartlands.

Labour did its best to make the election about anything other than Brexit. It played the NHS card, not unsuccessfully, appealing to the issue on which it is traditionally more trusted than the Conservatives and which is usually at or near the top of the list of voter concerns. It produced a manifesto that was jammed with expensive promises. Many of these had popular appeal. Nationalisation, particularly of industries like rail and water, has majority public support. Promising free broadband for all caught the public imagination.

In an age weary of austerity, the general commitment to increased public expenditure and an increased role for the state had resonance. This was a manifesto for all; the benefits pledged were largely universal, not just for the poor and vulnerable. Although portrayed as a deeply socialist agenda, the manifesto - if that had been the limits of what Labour delivered in government - would not have taken the UK out of the mainstream of European states in terms of the role of the state and the ratio of government expenditure to GDP. 
But the manifesto failed to carry conviction. While individual policies were popular, the whole was not credible with the electorate. Too many believed that it was not deliverable. This was down in part to the successful denigration of the manifesto by the Conservatives and the other parties. But it was perhaps due most to the distrust of the Labour leader, Jeremy Corbyn.

Corbyn went into the election as the most unpopular opposition leader for the last 45 years. ${ }^{3}$ This was a hurdle that any leader would have struggled to overcome but proved insuperable in an election where policy promises that might have had cut through in more normal times were simply overshadowed by Brexit.

In short, Corbyn failed to repeat the success that had rattled the Conservatives in 2017 and reduced them to a minority government. It turned out that the more the electorate got to know of him, the less impressed they were. He never dealt effectively with the accusations of systemic anti-Semitism in the party over which he presided. For many traditional Labour voters, he appeared to be unpatriotic and unsympathetic to their concerns and their view of the world. Throughout the campaign, reports from those canvassing on the doorstep confirmed that many in former Labour heartlands simply did not trust Corbyn or believe that he would govern in the country's best interests.

While far from universally popular in the country, Johnson, by contrast, at least hovered in more or less neutral approval territory. Despite some unforced errors on the campaign trail, notably an awkward handling of an incident when he was shown a picture on a phone of a young child lying on a hospital floor ${ }^{4}$, his appeal among his own supporters never wavered. Further, the Conservative manifesto, by itself committing to an end to austerity with increased expenditure promised on core public services, allowed Johnson and his team to portray themselves as something new, not a retread of the tired Conservative government of Mrs May. An end to austerity buttressed the promise to get Brexit done; it countered Labour's own electoral commitments and removed another reason for former Labour voters not to vote Conservative.

A combination of clarity on Brexit and widespread distrust of Corbyn were the key elements in the Conservative victory. Although their vote share only went up by $1.2 \%$, cut through on Brexit united the majority of Leave supporters behind them. Fear of a Corbyn-led government did the rest. For many Tory Remainers, the threat of a Corbyn government was sufficient to persuade them to swallow their EU-credentials and vote Conservative in spite of the promise of a hard Brexit. The Conservatives won an extra 47 seats to take their total to 365 . Enough former Labour voters either stayed at home or voted Conservative to reduce the Labour share of the vote by $7.8 \%$ and to lose them 59 seats, leaving them with only 203 , the party's worst result since 1935 . So ended the disastrous experiment with the Corbyn leadership.

The main image of the election outcome was undoubtedly the crumbling of the socalled Red Wall of Labour seats in the midlands and north of England. Seats that had voted Labour for decades fell to the Conservatives, in unlikely places like Bassetlaw, Great Grimsby, the Rother Valley and Blyth Valley.

This was a dramatic outcome, a sweeping change to the political geography of the UK that would have been unimaginable even a few years ago. But it reflected more than just poor opposition leadership and a deep disgruntlement with the prevarication of the political elite over Brexit. It was founded on the discontents that had driven the outcome of the EU referendum itself. 


\section{The Brexit effect} Outside of London, England voted by a margin of $11 \%$ to leave the EU. Tangled up in the disaffection that drove the Brexit vote was undoubtedly a new current of nationalism in England. The evidence suggests that those who identify most strongly as English rather than British were most likely to vote Leave. ${ }^{5}$ In socio-economic terms, these voters are more concentrated in working class rather than professional communities. In the 2019 election, the Conservative party was able to successfully appeal to their values in a way that overturned the traditional allegiance to Labour. The Conservatives won more voters in every social class than Labour. ${ }^{6}$ In the emerging world of identity politics, the unambiguous positioning of the Conservatives on Brexit, but also on the associated value set of flag, a tough approach on law and order and a marked disdain for 'wokeness', paid dividends.

\section{A divided polity}

Where does this leave the United Kingdom as a political country? Boris Johnson has successfully united the Conservatives around his position on Brexit, ending the long European agony of the party, not through compromise, but simply by overwhelming and marginalising the remaining pro-Europeans. The Conservative party is united. It 
will take an almost unimaginable political upheaval to dislodge the Conservatives from government over the course of this Parliament and Labour has a mountain to climb to be a credible contender for power at the next election. So are the divisions that have so scarred the country through and beyond the EU referendum now over? How secure is Johnson's hold on the affections of the nation?

On the surface, this was a decisive victory. But beneath the surface, the UK remains a divided polity, demographically, socially and geographically.

The British system of electing members of Parliament though individual constituencies on a first-past-the-post basis exaggerates the victory. The Conservatives won $56.1 \%$ of the seats but only $43.6 \%$ of the votes. The key to that outcome in the 2019 election lay in the ability of the Conservatives to hold most of the Leave vote, while the Remain vote was split between Labour, the Liberal Democrats and Greens. Far from being an overwhelming endorsement of Johnson's hard Brexit strategy, the majority of voters $52 \%$ - actually voted for parties who were opposed to, or ambivalent, about Brexit.

The UK left the EU on 31 January. The UK Government immediately embarked on the negotiations on the future relationship with the EU with a negotiating position at the hardest end of the Brexit spectrum. Seeking a free trade agreement based on the precedents of Canada, Japan and South Korea, the UK government has seemingly rejected any concession to a sense of a common European future. The relationship envisaged is a purely transactional one, with no overarching treaty, no acceptance that proximity and weight of trading relationship might require a closer alignment of standards in labour markets, competition policy, state aid and the environment. The UK government insists on its right to negotiate as an 'independent' country, free to strike its own trade deals across the world without any hindrance from obligations arising from a trade deal with the EU.

With a majority of 80 in Parliament, there is little doubt that the UK government will face no serious impediment to its negotiating stance from within the UK. Indeed, many on the Conservative backbenches will hold the government to account for the continued pursuit of a hawkish line. The government seems to view the possibility of a failure to achieve a trade deal in 2020 with equanimity, despite the evident risk of economic dislocation of a hard switch to trade on WTO terms at the end of the year.

It is not just on its own backbenches that the government will be under close scrutiny. The promise made to the electorate was crystal clear on Brexit. The government will be watching opinion in those constituencies which were the key to its victory very closely. That is why the strength of its Brexit commitment has been sustained through the early months of the coronavirus crisis. The whole meaning of this government is founded on its unambiguous rejection of a close European future.

\section{Challenges ahead}

How will those who did not vote Conservative adjust to this new reality? The dream of overturning the 2016 referendum result is dead, at least for the foreseeable future. Does this mean, then, an end to the Brexit divisions? Will former Remainers accept their defeat and reconcile themselves to a future for the UK that will be very different to the one they imagined? 

years. Economic arguments alone are unlikely to settle the issue. By the government's own estimates, the sort of Brexit now being pursued will have an adverse impact on GDP growth of up to $6.4 \%$ over a 15 -year time horizon. ${ }^{7}$ Also by the government's own estimates, even an ambitious UK/US trade deal will not offset that loss of growth by more than $0.16 \%^{8}$ and other trade deals will be even less productive of new growth. Some sectors will be hard hit by the disruption to supply chains built up through seamless trade in the single market. Lost jobs will be visible but lost growth is not; people are unlikely to miss what they have never had. The causality of the factors that drive the UK's economic fortunes in the near term will be hotly disputed and will be further complicated by the economic shock caused by the coronavirus pandemic.

(henents of the questions of identity and associated values that were in any event more influential in the election outcome? Does the Conservative victory signal an end to the debate about how the UK should hold itself in the world?

40

the the answer to that question lies in the demography of the election outcome. While the Conservatives won more votes than Labour in every social class, the age profile was very different. $57 \%$ of 60 to 69 year old's voted for the Conservatives, but only $21 \%$ of 18 to 24 year old's. ${ }^{9}$ As was evident in the EU referendum itself, the younger part of the population is more likely to be pro-European. ${ }^{10}$ They are more likely to cite the environment as a key concern..$^{11}$ They are more likely to hold socially liberal values. ${ }^{12}$ This demographic division is evidenced too in the geography of the election, with the Conservatives doing relatively less well in London and the other metropolitan cities and in university towns.

In the immediate aftermath of the election and formal exit from the European Union, there was no banner behind which this swathe of public opinion could rally. Labour was in no position to articulate a resonant campaign of opposition, not least due to an interminable leadership campaign. Even now that Labour has a new leader in Keir Starmer, the old tension in the party remains. Although the UK's departure from the EU takes one argument off the table, it does not end the tension between the different values of those with a more socially liberal and internationalist outlook and those who cleave to a more traditional value set founded on national identity.

The choice that Keir Starmer makes for the Labour party will be of profound significance for British politics. Does he prioritise an endeavour to compete with the Conservatives to win back the lost heartlands, fighting on traditional leftwing territory? Or does he seek to position the Labour party as the unambiguous standard bearer of socially liberal values, occupying the opposite pole to the Conservatives on the new spectrum of identity politics?

43 It will take some time for the Labour party under its new leadership to find its feet, some time before it is clear whether or not the party can provide a uniting home for those who feel their values are not represented by the Conservative government. If Labour fails to rise to that challenge, there will be a vacuum in British politics for the many millions, particularly of young people, unreconciled to Johnson's vision of Britain's future. How these people find voice will determine the character of British politics for many years to come. 

the very future of the United Kingdom is at stake.

\section{Four elections in one} and more open attitudes towards unification among the young, this sets Northern Ireland on an uncertain course. Under the terms of the Good Friday Agreement, the Secretary of State for Northern Ireland in the UK government is obliged to hold a border poll if public opinion appears to be in favour of unification. A border poll is unlikely to be imminent; some recent opinion polls have support for unification at or close to $50 \%$, but others as low as $35 \% \cdot{ }^{13}$ However, the trend of opinion appears to be consistent over time, towards support for unification. Parliament and beyond. Prime Minister Johnson still has to wrestle with the complex and controversial problems of how to manage the Northern Ireland dimension of the Withdrawal Agreement; reaching agreement with the European Commission on the precise management arrangements is complex. This will keep the Brexit impact on Northern Ireland at the forefront of political concerns. There will be little credit for the government in whatever outcomes they eventually achieve; opinion on the mainland is broadly indifferent to the future of Northern Ireland in the UK. ${ }^{14}$

51 Almost the only certainty about Northern Ireland over the next few years is that it will continue to demand priority attention from the UK government. How sensitively the 
government responds to those demands could determine whether that trend in favour of unification is stayed or accelerates.

An even more immediate threat to the integrity of the United Kingdom comes from Scotland. The Conservatives did not win the election in Scotland. Indeed, they lost 7 of the 13 seats they had won in 2017 and garnered only $25.1 \%$ of the vote. The election instead provided the platform for another sweeping victory for the SNP, who took $45 \%$ of the vote and increased their number of seats by 13 to 48 . The Liberal Democrats held on to only 4 seats and Labour, not so many years ago by far the dominant political power in Scotland, was reduced to a pitiful single seat.

As for the Conservative party at the UK level, normal political expectations would have suggested that this was an election that should have punished the SNP. In power in Scotland at the time of the election for over 12 years, the SNP has presided over a Scottish government with a less than compelling record in domestic Scottish politics. With well-advertised failings in education policy and the health service, with recent controversy over contracts to build ferries and let ferry routes and with the unsavoury spectre of the trial of former SNP First Minister Alex Salmond on charges of sexual assault and attempted rape hanging over them, the SNP was ripe for an electoral beating.

54 Yet the SNP reversed the relative set back they had experienced in the 2017 election. Why were they able to defy electoral gravity?

The answer lies in that same shift of political allegiance towards choices based on identity, a road down which Scotland was already well advanced. The 2014 referendum on Scottish independence had the same effect on Scottish opinion as did the $2016 \mathrm{EU}$ referendum across the UK; it divided people around the core question of sovereignty. In a test case of how the divisions caused by referendums are slow to heal, Scottish opinion on the question of independence did not shift markedly from the 45 for/55 against outcome of the 2014 referendum until 2019, when there was a modest but sustained increase in support for independence, taking it up to the $50 \%$ mark in a series of polls in early 2020, thereby confirming that Scotland is a land divided down the middle. $^{15}$

The reasons for the uptick in support for independence seem clear; some people who voted no to independence in 2014 and Remain in the EU referendum have moved towards support for independence. There has been a smaller drift the other way, as Leave voters who had previously supported independence choose to prioritise EU exit over Scottish independence. But the net result is clear; Brexit has increased support for independence in Scotland.

57 This is an existential challenge for the Johnson-led government and one that it is illequipped to handle. His brand of Tory-ism does not travel well in the north of the country; there is little prospect of a resurgence of support for the UK Union on the back of affection for this Conservative government. Meanwhile, at a deeper level, the things that once held the concept of Britishness together, Protestant religion, empire and foreign wars, the welfare state and even the armed forces and the monarchy, no longer resonate in Scotland as they once did.

Only the National Health Service still serves as a beacon of British solidarity. Perhaps the coronavirus crisis will reinforce that last sinew of the UK Union, in time to dent the hopes of the SNP of winning a majority in the 2021 elections to the Scottish Parliament. 
But it is likely to be a close-run thing. If the SNP and their allies do indeed win that election on a mandate for another referendum, that will pose a huge challenge to the UK government which, under the devolution settlement, has to agree to the holding of a referendum to make it legal.

Most governments are remembered for things they didn't expect or want to be remembered for. That maxim has already been proved true for Boris Johnson in the shape of coronavirus. But there could be another longer-lasting and constitutionally seismic legacy; the very rupture of the Union of the United Kingdom.

What about Wales? On the face of it, the 2019 election outcome in Wales reflected the pattern in England. Labour, for over a century the dominant party in Wales, still topped the poll in terms of vote share and seats but lost share of both - vote share down $8 \%$ to $40.9 \%$ and number of seats down 8 to 22 . The Conservatives meanwhile won their highest ever share of the vote, up $2.5 \%$ to $36.1 \%$ (and would probably have gone higher if the Brexit party had not taken $5.4 \%$ of the vote) and equalled their previous best tally of 14 seats, almost wiping Labour out in North Wales.

61 The same factors were in play as in England; a combination of a decisive position on Brexit and deep distrust of Jeremy Corbyn. Plaid Cymru, the Welsh nationalist party, could not replicate the success of the SNP in Scotland, marginally losing vote share to $9.9 \%$, but hanging on to their four seats.

So can Prime Minister Johnson assume that in Wales he will face no serious challenge to the existing order of the UK, at least for the term of this Parliament? Possibly, but the nature of Welsh politics is changing too. As elsewhere, identity is thrusting into the political equation. Some of that vote for the Conservatives is an assertion of Britishness, particularly on the part of voters of English origins. Part of the problem for the Labour party in Wales, beaten into third place in the 2019 European Parliamentary elections by the Brexit party and by Plaid Cymru, is their equivocal position on the question of identity.

Welsh Labour, particularly under the leadership of Carwyn Jones when he was First Minster, managed to sit astride the identity line, standing up for Welsh interests while supporting the Union of the UK. But that was always a weak strategic position. Labour in Wales risks being outflanked, as Labour has been in Scotland, by the Conservatives on the one hand as the natural defenders of the Union and Plaid Cymru, now under the more dynamic leadership of Adam Price, as the natural promoters of the Welsh national interest.

So is Wales on the cusp of the sort of transformation that Scotland has witnessed, with the collapse of the Labour party and politics realigned on identity lines? The contest in the 2021 elections to the Senedd, the Welsh Parliament, will be watched with keener interest than usual in the corridors of Westminster.

This is not a nation united. Brexit has brought further uncertainty to the already fragile polity of the United Kingdom. With a de facto trade border down the Irish Sea, the aftermath of Brexit may reinforce the existing slow trend in Northern Ireland towards majority support for unification. Scotland is divided, many still bitter at the foisting of Brexit on a nation that did not vote for it, and with a powerful political force in the shape of the SNP capable of winning a majority in the 2021 elections to the Scottish parliament. The old order in Wales is showing signs of decay, with Labour struggling to assert its traditional dominance. 

government has taken a far from conciliatory line. It appears to be playing fast and loose with the Northern Ireland protocol, despite the deep sensitivities that accompany any political uncertainty in the province. There has been no attempt to reach out to the Scottish or Welsh governments on Brexit or, over their heads, to the people of Scotland and Wales. The government's agenda is driven by other political concerns. 


\section{Conclusion}

Prior to the outbreak of the coronavirus pandemic, all the signs were that the government intended to rule as it had campaigned in the election, driving a hard Brexit, appealing to the values and cultural mores of the communities that had found in the campaign to leave the EU a clear expression of their political identity. Coronavirus complicates everything, although it is too early to say that it changes everything, at least in politics. As often in a national crisis, the initial reaction of the British public was to lock in behind the Prime Minister; Boris Johnson's ratings soared. 16

But the crisis and its aftermath will be long in the resolution. There will be a reckoning, as inquiries examine why decisions were taken as they were and apportion blame. Economic dislocation will cause discontent. Will the government stick to its hardline approach to Brexit and espousal of divisive identity politics? Or will it relent in the face of a need for national renewal and seek to reach out across the cultural divide? Will there be an opportunity for Labour to rekindle the old alliance between the working class of the north and midlands and the professional classes of the metropolitan areas? What seemed so decisive on the morning of 13 December 2019 no longer looks so clear. A handsome majority in the House of Commons masks fundamental divisions in the country. Coronavirus poses challenges unimagined even a few short months ago. Far from advancing on a settled course, British politics continues to deal in profound uncertainty.

Philip Rycroft is an Honorary Professor at Edinburgh University and a Senior Distinguished Visiting Fellow with the Bennett Institute for Public Policy at the University of Cambridge. Between 2012 and 2019 he was the senior civil service adviser to the UK Prime Minister and other Cabinet ministers on constitutional and devolution policy in the UK. Between 2017 and 2019 he was also led the Department for Exiting the EU in the UK government.

\section{NOTES}

1. https://lordashcroftpolls.com/2019/12/how-britain-voted-and-why-my-2019-generalelection-post-vote-poll/

2. https://yougov.co.uk/topics/politics/articles-reports/2019/12/17/how-britain-voted-2019general-election

3. https://www.ipsos.com/ipsos-mori/en-uk/jeremy-corbyn-has-lowest-leadership-satisfactionrating-any-opposition-leader-1977

4. He snatched the phone off the journalist.

5. 2018 - 54\% English, not British; 24\% British, not English British Social Attitudes 36 The EU Debate

6. https://yougov.co.uk/topics/politics/articles-reports/2019/12/17/how-britain-voted-2019general-election 
7.

https://assets.publishing.service.gov.uk/government/uploads/system/uploads/ attachment_data/file/760484/28_November_EU_Exit___Long-term_economic_analysis__1_.pdf https://assets.publishing.service.gov.uk/government/uploads/system/uploads/ attachment_data/file/869592/UK_US_FTA_negotiations.pdf

9. https://yougov.co.uk/topics/politics/articles-reports/2019/12/17/how-britain-voted-2019general-election

10. In $201819 \%$ of $18-34$ year olds in favour of leaving compared to $49 \%$ of $55+$ British Social Attitudes 36 The EU Debate

11. https://yougov.co.uk/topics/politics/articles-reports/2019/11/22/general-election-whowill-win-youth-vote

12. https://assets.publishing.service.gov.uk/government/uploads/system/uploads/ attachment_data/file/389086/Horizon_Scanning_-

_Social_Attutudes_of_Young_People_report.pdf

13. https://www.belfasttelegraph.co.uk/news/northern-ireland/just-29-in-northern-irelandwould-vote-for-unity-major-study-reveals-38966196.html

https://lordashcroftpolls.com/2019/09/my-northern-ireland-survey-finds-the-union-on-aknife-edge/

14. https://www.ipsos.com/ipsos-mori/en-uk/one-three-britons-would-mind-if-northernireland-voted-leave-uk-poll-finds

15. https://whatscotlandthinks.org/questions/how-would-you-vote-in-the-in-a-scottishindependence-referendum-if-held-now-ask/?removed

16. https://yougov.co.uk/topics/politics/trackers/boris-johnson-approval-rating

\section{ABSTRACTS}

The outcome of the UK General Election of December 2019 was a substantial victory for the Conservative party. Why did the Conservatives win, and win so well, when the party had been bitterly riven for over three years by deep disagreement about Brexit? This chapter analyses the reasons for that success and asks what this says about the politically unity of the United Kingdom. It argues that, beneath the surface of a decisive electoral outcome, the UK remains a country divided, demographically, socially and geographically. The future course of British politics remains uncertain.

Le résultat des élections législatives britanniques de décembre 2019 a constitué une victoire importante pour le parti conservateur. Pourquoi les Conservateurs ont-ils gagné, et avec une telle ampleur, alors que ce parti avait été âprement déchiré par de profonds désaccords au sujet du Brexit au cours des trois dernières années? Cet article analyse les raisons de ce succès et sa signification par rapport à l'unité politique du Royaume-Uni. Il postule que derrière l'apparence d'un succès électoral décisif, le Royaume-Uni demeure un pays profondément divisé, aux plans démographique, social et géographique. L'avenir de la politique britannique demeure incertain 
INDEX

Mots-clés: élections législatives, Parti conservateur, Parti travailliste, Brexit, Union britannique

Keywords: general elections, Conservative Party, Labour Party, Brexit, British Union

\section{AUTHOR}

\section{PHILIP RYCROFT}

Edinburgh University 